\title{
Recent Journeys in Persia
}

\section{Author(s): P. Molesworth Sykes}

Source: The Geographical Journal, Vol. 10, No. 6 (Dec., 1897), pp. 568-594

Published by: geographicalj

Stable URL: http://www.jstor.org/stable/1774906

Accessed: 27-06-2016 02:30 UTC

\section{Your use of the JSTOR archive indicates your acceptance of the Terms \& Conditions of Use, available at}

http://about.jstor.org/terms

JSTOR is a not-for-profit service that helps scholars, researchers, and students discover, use, and build upon a wide range of content in a trusted digital archive. We use information technology and tools to increase productivity and facilitate new forms of scholarship. For more information about JSTOR, please contact support@jstor.org.

The Royal Geographical Society (with the Institute of British Geographers), Wiley are collaborating with JSTOR to digitize, preserve and extend access to The Geographical Journal 
of the archipelago known as Franz .Tosef Land. T'he first has not yet been attempted. With regard to the second, we hear of two contemplated undertakings. Mr. Peary intends to adopt the plan of taking. Eskimo families up Smith sound, and, with their aid, to discover the most northern land to the north of Greenland. Captain Sverdrup, Nansen's companion, is fitting out the Fram, also with the intention of proceeding up Smith sound and exploring the unknown part of the north coast of Greenland. I greatly fear that neither Peary nor Sverdrup have any adequate conception either of the difficulty of navigating the channels beyond Smith sound, or of travelling over such ice as is met with beyond Robeson strait. This was not the route I recommended for completing the discovery of the Greenland coast, an achievement second to none in geographical interest. The third enterprise enumerated by me in 1877, namely, the North-East Passage, was achieved by Baron Nordenskjöld three years afterwards. It was reserved for the Jackson-Harmsworth expedition to achieve the fourth-the exploration of Franz Josef Land.

We now have to welcome Mr. Jackson, Mr. Armitage, and the other members of the expedition on their safe return, and to congratulate $\mathbf{M r}$. Harmsworth on the valuable results of his patriotic munificence. Our explorers have passed three consecutive winters in the arctic regions close to the 80th parallel. They have maintained themselves in excellent health throughout that long and trying period; they have diligently registered observations, and have completed exhaustive researches in the zoology, botany, and geology of a new region. This alone is a great work; but it is only a small part of what has been done under Mr. Jackson's command. That explorer, always, I believe, accompanied by $\mathrm{Mr}$. Armitage, has made daring sledge-journeys and boat-voyages, and by these means he has given us a completely new idea of Franz Josef Land. In this present year, by the examination, under exceptionally trying and difficult circumstances, of the land mass to the westward, I think he has surpassed all he had done before, and it will now be our privilege to hear, from Mr. Jackson's own lips, the interesting story of his expedition and its work.*

\section{RECENT JOURNEYS IN PERSIA. $\dagger$}

By Captain P. MOLESWORTH SYKES.

The ancient kingdom of Persia, to which I would draw your attention this evening, is perhaps one of the most attractive countries in the world, as not only is it rich in remains of a hoary antiquity, which

* Mr. Jackson's paper will appear in a future number of the Journal.

+ Paper read at the Royal Geographical Society, June 28, 1897. Map, p. 660. 
have been the constant theme of historians for more than two thousand years, but to-day it presents so great a variety of interesting problems, and has so faithfully preserved its ancient immutable civilization, that every traveller who has once crossed its great plateau is fired with the desire to return again and again. Before approaching the subject of my three journeys, I would give a brief description of the country upon which we are about to enter.

The kingdom of His Imperial Majesty the Shah stretches, roughly speaking, for 1000 miles from east to west, and for 800 miles from north to south - an area rather larger than that of the countries composing the Triple Alliance. In the provinces which border the Caspian sea the rainfall is very heavy, but, with that small exception, the most noticeable feature is the dryness of Persia, and this is the main cause of its delightful climate. I have mentioned this before anything else, as it appears to me that sufficient attention has not been paid to the enormous effect that deforestation has had, not only on Persia, but on Central Asia generally. It is this fact, and this alone, I would urge, that explains how great armies were able to march across countries the sterility of which would, at the present time, bar the progress of anything beyond a very moderate force; and, conversely, it is upon the successful solution of this problem that the future of these desiccated.regions ( $\mathrm{I}$ use the term advisedly) depends.

To continue, both on the north and south, the great Iran plateau is held up by mighty ranges, which are traversed by mule-tracks, and it is owing to the rugged nature of these passes that the isolation of Persia from the rest of the world is partly due. The plateau once reached, the traveller finds himself on a series of broad plains with mountain ranges on each side of him, which trend to the north-west with amazing regularity. For instance, when travelling to my district of Kerman, a distance of 600 miles from Tehran, I traversed the same great plain throughout, and never lost sight of the two parallel ranges at any portion of my journey. These mountains, which rise to great elevations, are, as my previous remarks would show, entirely bare of timber, while the whole country consists of desert with rare oases, dependent for their existence upon "kanats." By this term, underground channels which tap distant springs in the hills are signified, and it may be imagined how costly and laborious a system this is, the water being frequently carried a distance of over 30 miles to the village it supplies.

There are no navigable rivers in Persia, with the exception of the Karun, and it is extraordinary that between the Indus and this river, a distance of 1500 miles, no considerable body of water reaches the sea. To the north, owing to the heavier rainfall, it is different, and there are two or three rivers of moderate volume flowing into the Caspian sea.

This summary would not be complete without a reference to the 
appalling wastes known respectively as the Dasht-i-Kavir and the Dashti-Lut. These two great deserts stretch right across Eastern and Central Persia, with the result that there is much less communication between neighbouring provinces of the Persian Empire than their juxtaposition would lead one to expect, the wastes of salt-swamp and sand dividing the districts more completely than any range of mountains, however difficult its passes might be.

It was at the beginning of 1893 that I obtained permission to rejoin the "Bays," at that time stationed in the Punjab, viâ Persia, and I first of all travelled to Odessa, where Colonel C. E. Stewart, Her Majesty's consul-general, and a prominent Fellow of this Society, not only gave me much valuable advice, but also furnished me with letters of introduction. In consequence, I did not enter Persia by the usual route, but crossed from Baku to Uzun-Ada, the starting-point of the Transcaspian railway, and thence steamed down the eastern coast of the Caspian to its southeast corner. At Ashurada, we lay to off the Russian naval station for a few hours, and soon after reached the end of the "Murdab," or lagoon, where we rowed through myriads of duck and every sort of aquatic bird, to the rickety pier of Bunder Gez, after traversing which, we found ourselves nearly up to the knees in mud. There being no hotel, and tents being out of the question, we were only too glad to find quarters at the telegraph office, where a room was placed at our disposal.

After two days' delay, we started for Astrabad in wet weather, and enjoyed a very full experience of what muddy roads can be. The mules were not so badly off, their loads being high up on their backs; but the ponies, which carried my servant and myself, must have been very weary, as we could hardly ever keep our feet out of the mud, so deep was it. Five hours' marching through the mire only brought us 7 miles on our way, but, as we were told that the road upon the morrow was much better, we decided to halt for the night, and found quarters in the village of Kurd Mahalla, in the house of its headman. Our host professed himself a profound theological student, and, after introducing the subject generally by stating that all Europeans worshipped machines, was anxious to know whether we English worshipped a steamer or a locomotive.

On the following morning the country, which had hitherto been a melancholy tangle of low thorns and bushes, became quite park-like, and, as it cleared up, matters looked more cheerful. On passing through the village, which covers a large area, we saw wheat being thrashed by means of a see-saw-a girl sitting on one end of the plank, and pulling herself up and down by a rope suspended above her. It was nearly sunset when, amid a deafening chorus of jackals, we entered the city of Astrabad, through a dilapidated gate. Inside not a soul was to be seen, and we rode on for a considerable distance before we pounced upon a 
stray citizen, whom we induced to guide us to the house of the British agent. My first inquiries were as to the possibility of travelling up the river Atrek to Bujnurd, but my host told me that the country was so disturbed, that the Persian Government would insist on sending a large escort with me, which would have effectually prevented my mixing with the Turkomans, and so I determined not to seek any aid from the authorities.

For about a week I made constant shooting-trips into the Elburz range, during the course of which I bagged a few wild boar, but saw no sign of the magnificent stags that roam the forests. Meanwhile my

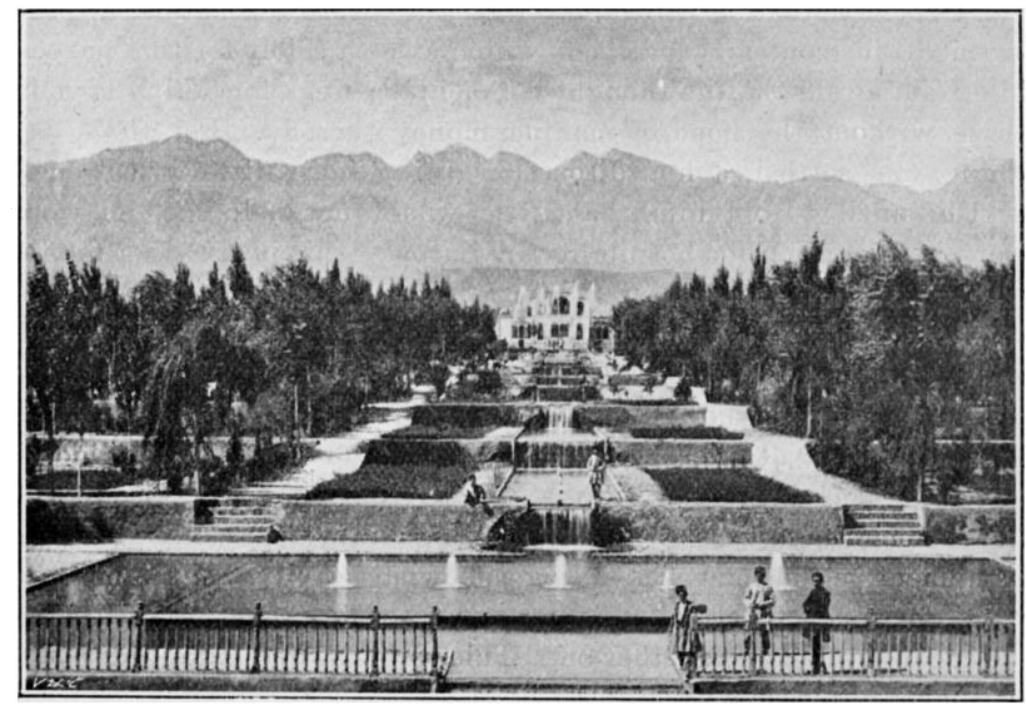

THE FARMAN FARMA'S GARDEN AT MAHUN.

preparations were being made, and upon their completion, I marched off due north across a rich alluvial plain, until we sighted Ak-Kala, a fort that commands the bridge over the Gurgan, and the home of the Kajar tribe, whose chief is now Shah of Persia. We then turned due east, and followed up the river, until we reached the encampment of Moussa Khan, the chief of the Ak Ata Bai, the most powerful tribe of Yomut Turkomans. The camp consisted of about thirty " alachuk," and as I lived in these superior nomad dwellings for nearly a month, it might be as well to describe them.

We must first of all imagine a huge beehive framework of wood, some 16 feet in diameter; over this thick black felt is stretched, and we have an ideal movable house, which, in cold weather, is infinitely superior to any tent. Inside are the "lares and penates," packed up in big trunks, while the rifles of the owners hang within easy reach. 
Strips of carpet are stretched round wherever there are joinings in the felt, and altogether, when the fire is lit on the hearth, one enjoys a feeling of real comfort.

I had a letter of introduction from Colonel Stewart for my host, and in it my plan of travelling up the Atrek was mentioned. Moussa at first, however, utterly declined to help me, averring that I was sure to be robbed, if not killed, in which case he would be held responsible by the Persian Government. He was also at a loss to know the object of my journey, and, as Colonel Stewart had not mentioned that I was an officer travelling on leave, I told him that I was a Fellow of the Royal Geographical Society. When he found out that the object of this Society was the collection of geographical information; he could not conceal his contempt for a body which existed solely for this purpose, while I am afraid that he thought me mentally weak for taking so much trcuble without the hope of making money thereby. For three days nothing was settled, a hot discussion being eternally carried on in Turkish, until I told him that if he would not help me, he would lower his reputation for hospitality in Europe-this is always a terrible threat-and, as I also presented him with a revolver, he finally agreed to send me on to the Atrek, where further arrangements would be made.

It was across the snowy steppe that we marched, after bidding farewell to our host at the ford of the Gurgan, or Wolf river, which is apparently the same as Hyrcania, the Greek name for this district. After a long day we sighted the Atrek, and were glad to reach an encampment, as the snow was falling somewhat heavily. In the morning I was informed that forage for the next five stages must be bought, as none could be procured further on. This was followed by an intimation that I must purchase a camel for $£ 40$ to carry it. Fortunately, I guessed that the desire to sell me a camel at five times its value was the reason for the alleged scarcity of barley, so I declined to do anything but move on. This was not so easy, as the Yomut Turkomans are very loth to speed the parting guest without first fleecing him, so that it was noon before the march was resumed, more or less parallel to the yellowcoloured Atrek; to which river, as to the Tiber, the epithet of "flavus" is most appropriate. Our way lay across what should be a fertile country, but the treeless, snow-covered steppe looked extremely dreary, and, to add to our discomfort, no meat was procurable, as all the sheep were dying of some disease, and we had, consequently, to depend upon shooting a few pigeons, which were hard to approach.

For two or three days we were accompanied by a " mollah," or priest, and, under his guidance, we steadily ascended the left bank of the Atrek, as far as a point opposite Chat, where we forded the river, and followed up the right bank through a mass of low hills. Our escort consisted of three or four Turkomans, who, whenever they met another 
party, took the most warlike precautions, until they discovered whether those approaching were friends or foes. About 20 miles above Chat our priestly guide intimated that he was going no further, so, before continuing our march the next morning, I sent him a silver watch and a present of money. However, he returned them without thanks, and intimated that he would like my telescopic-sighted rifle, which he had greatly admired. At the same time the muleteers came in weeping, and said that the Turkomans were going to take their mules and also rob me. I tried to quiet them, and sent my servant into the "alachuk" to harangue the heads of the tribe, while I got the mules loaded

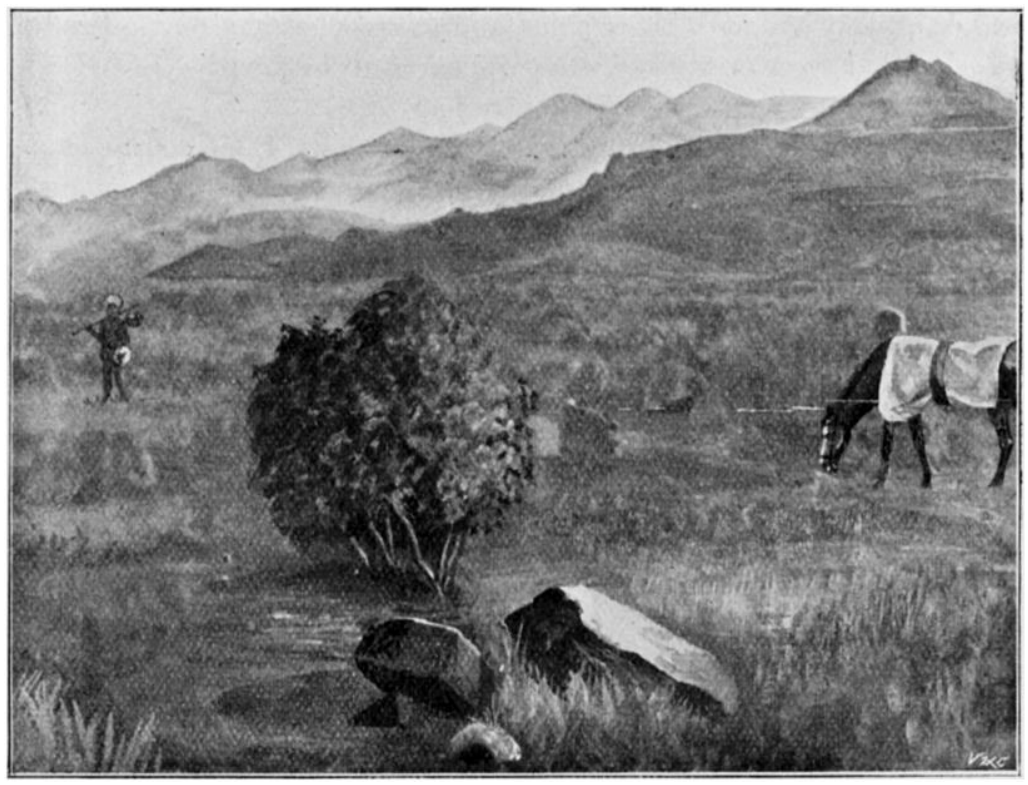

THE TAFTAN RANGE, SARHAD.

up. For an hour we waited, hearing only a stormy flow of Turkish from the council-room, so, when the mules were ready, I thought that I had better see what was going on. I found Joseph dancing about in an agitated state, and upon my entrance he told me that they plainly spoke of robbery, and would not let us leave. $\mathrm{He}$ advised the rather foolish expedient of attacking them; but, instead, I told him to say how I loved the mollah, and I patted that scoundrel so violently on the back to show my affection, that he could not go on speaking.

The Turkomans thought it very funny, and when I ran the mollah outside, they brought his horse, and he came along with us just as if everything had been arranged to his satisfaction. I forgot to mention 
that, before the acute stage was reached, I was asked to give a letter for him to show in case of complaints. In it, I wrote that I expected to be robbed, and only hoped that any future traveller would have him punished, had he the chance. Before saying good-bye to our friend, who only accompanied us for a couple of miles, I offered to give him a second note. This he felt sure would not be as laudatory as he imagined the first to be, so be said that the former one would suffice, and I am confident that he considers it to be couched in the most complimentary terms. That night we were not asked into the village near which we halted; so, surmising from this pointed lack of hospitality that treachery was intended, we kept watch. At about 2 a.m. some six or seven Turkomans sneaked quietly out with their rifles, and approached the tent. Finding, however, that we were awake, they appeared to be surprised, and, after talking together, went quietly back to bed.

As we were close to the country of the Goklans, I decided to change my tactics, and on the following morning abused the Turkomans for their violation of hospitality, and threatened them with the vengeance of the Governor of Bujnurd, who was, I said, a great friend of the British Government. This bluff, which, I am sure, lost nothing when interpreted into Turkish, had its effect, and our guides, finding the game up, rode away, and, after firing a few shots at us from about half a mile off, to which we made no reply, left us in peace.

The Goklan Turkomans received us in quite a different manner, and said that Huck Nafass, our mollah, was not only "wanted" by the Persian Government for several acts of robbery, but that any Goklan would shoot him on sight, had he an opportunity. I was consequently delighted to feel that I had escaped from his clutches without harm, and can only put it down to the fact that, although I was without an escort, he imagined that I held some very strong cards up my sleeve. We were soon joined by Mustapha Kuli, who had been Captain Napier's guide in 1877, and it is, I think, thanks to him that I was so well treated.*

\section{* Note on the Yonut and Goklan Turkomans.}

(a) Jafar Bai.-This tribe inhabits the district near the mouth of the Atrek, and, as regards wealth, may be considered the most important division. They possess fisheries, and also cultivate more extensively; in addition to this, they engage in commerce.

The Jafar Bai have two divisions of Yarali and Norali, and number 2000 families to the south of the Atrek, and 1000 families to the north. They are generally on bad terms with the Ata Bai, their neighbours to the east.

(b) Ata Bai.-The Ata Bai include 2000 families to the south of the Atrek, and 1000 to the north. Although not as rich as the Jafar Bai, the Ata Bai have more power, as many of the smaller divisions are under their protection.

There is a subdivision called Ak Ata Bai. Ak = white.

(c) Friendly to, or perhaps under the protection of, the Ata Bai are the following divisions :- 
We were told that the road to Bujnurd lay across the Hanaki pass to the south, and that we were to quit the Atrek, up which we had been marching hitherto. The cold was intense, although it was the middle of February, but once over the pass we descended rapidly, until, at Semalgan, two marches further on, we found the heat quite oppressive.

Before reaching the town of Bujnurd, we had to cross another range of hills, where the fresh snow was so deep that it took us

$\begin{array}{lcccccccc}\text { Gangokmuz } & \ldots & \ldots & \ldots & \ldots & \ldots & \ldots & 400 \text { familiı s. } \\ \text { Bolgai } & \ldots & \ldots & \ldots & \ldots & \ldots & \ldots & 300 & , \\ \text { Daz } \ldots & \ldots & \ldots & \ldots & \ldots & \ldots & \ldots & 1000 & , \\ \text { Dovoji } & \ldots & \ldots & \ldots & \ldots & \ldots & \ldots & 1000 & , \\ \text { Badragh } & \ldots & \ldots & \ldots & \ldots & \ldots & \ldots & 200 & ,\end{array}$

These divisions are generally on terms of feud with-

$\begin{array}{lcccccccc}\text { Amir ... } & \ldots & \ldots & \ldots & \ldots & \ldots & \ldots & 100 \text { families } \\ \text { Kuchik } & \ldots & \ldots & \ldots & \ldots & \ldots & \ldots & 301 & , \\ \text { Tatar ... } & \ldots & \ldots & \ldots & \ldots & \ldots & \ldots & 100 & , \\ \text { Salak ... } & \ldots & \ldots & \ldots & \ldots & \ldots & \ldots & 100 & , \\ \text { Kujuk } & \ldots & \ldots & \ldots & \ldots & \ldots & \ldots & 1000 & ,\end{array}$

To summarize, of the Yomut tribe there are 8500 families in Persian territory, and 2000 in Russian territory to the north of the Atrek.

Perhaps 20 per cent. of the tribes on either side cross the Atrek in order to change their pastures; but this custom is on the decline, as a tax is charged on all the tribesmen who graze their flocks on the northern bank. All the Yomuts profess to be at feud with the Goklans, who are now a much weaker and quieter tribe than formerly.

\section{Goklan Turkomans.}

The following divisions inhabit Russian territory to the north of the Atrek, on the road between Kizil Arvat and Bujnuri.

$\left.\begin{array}{lllllll}\text { Sorali } & \ldots & \ldots & \ldots & \ldots & \ldots & \ldots \\ \text { Toktamash } & \ldots & \ldots & \ldots & \ldots & \ldots & \ldots \\ \text { Kek } & \ldots & \ldots & \ldots & \ldots & \ldots & \ldots \\ \text { Kal Guzl } & \ldots & \ldots & \ldots & \ldots & \ldots & \ldots \\ \text { Ak Kal } & \ldots & \ldots & \ldots & \ldots & \ldots & \ldots\end{array}\right\}$

The following subdivisions inhabit Persian territory :-

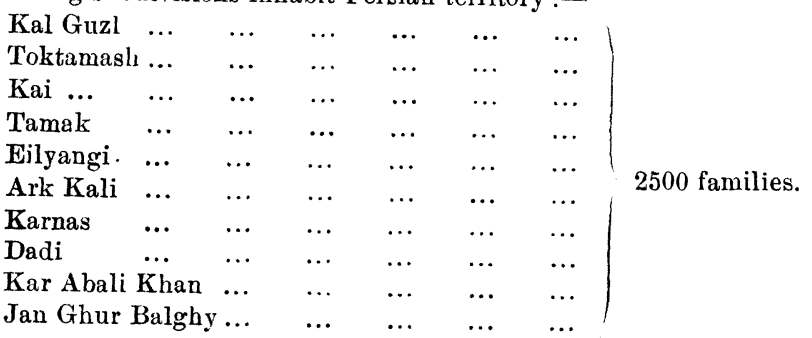

In former times the Goklan country was famous for its breed of horses, but, owing. to its proximity to tho powerful chief of Bujnurd, the tribe is now very quiet and weak, while its horses have shared in the general decline. 
hours to accomplish even a few miles. Upon reaching the plain, whereon lies the city, I had my first experience of an "istakbal," or reception, a troop of Persian cavalry escorting us to the town, where we were lodged in one of the governor's houses. When we went to pay our respects, we were conducted up the winding staircase of a tower into the presence of the Sani-i-Dowleh, the redoubtable warden of the marches, who, for fifty years, has been warring against the

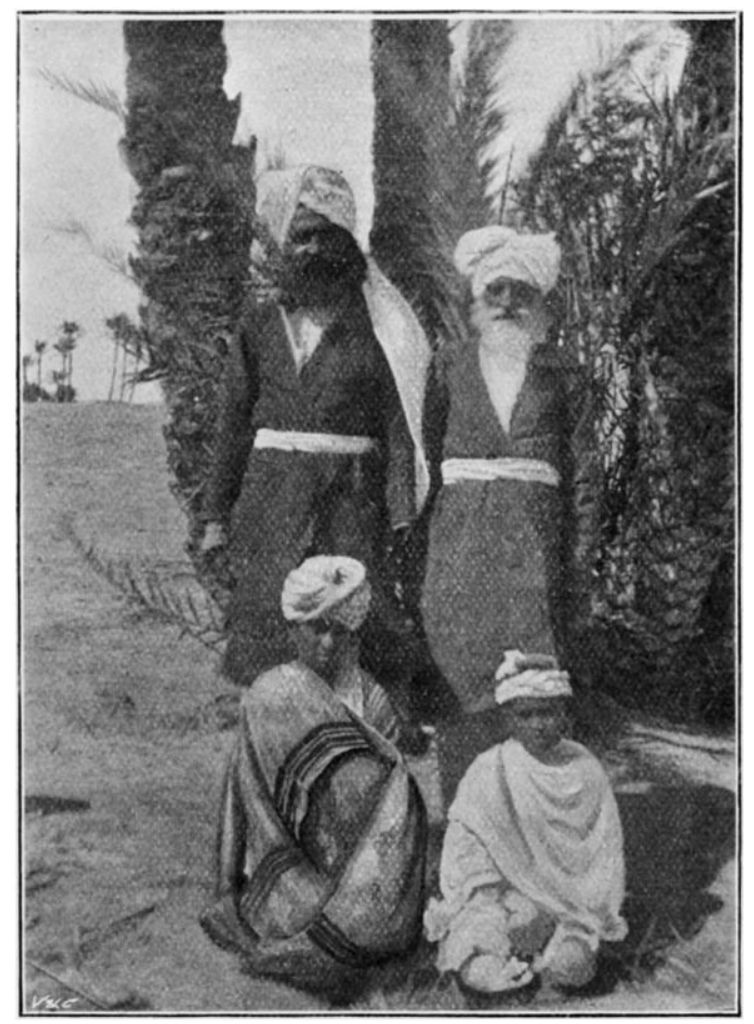

THE GOVERNOR OF MAGAS AND FAMILY.

Turkomans. His Excellency told me, that when he was a young man it was almost impossible to till the fields, and that at Bujnurd there were generally some hundreds of Turkoman prisoners, waiting to be ransomed or exchanged for captive Kurds. Nowadays there is comparative peace, cattle-lifting on a small scale having taken the place of the wholesale raids of the good old times.

My experiences among the Turkomans will show that they are still a somewhat wild and lawless race, but, from a reference to the pages of the great traveller, Vambéry, one can see how much Russia has 
benefited Central Asia generally, and Persia in particular,by suppressing the Turkoman terror. These freebooters raided North-East and Central Persia down to the Dasht-i-Lut, while every man, woman, and child that was captured would be sold into lifelong slavery, and also endure religious persecution at the hands of their Sunni masters. Prof. Vambéry has told me that he observed such innumerable cases of cruelty towards Persian captives that, although he personally was well treated, he regards the T.urkomans with abhorrence. I should have mentioned that both Bujnurd and Kuchan are peopled by Kurds, whom Shah Abbas (the contemporary of Queen Elizabeth) transported from his north-west to his northern frontiers, in order to form a bufier between Persia and the Turkomans. The experiment may be considered to have been a success, as the Kurds are splendid fighters, and have never been greatly worsted by the Turkomans.

The town of Bujnurd, which is situated on a fair-sized and wellwatered plain at an elevation of 3800 feet, contains perhaps 20,000 inhabitants, and is increasing at a rapid rate. The bazaars are extensive and well stocked with Russian and English goods, sugar, hardware, and crockery coming from Russia, while the calico and muslin bore Manchester or Bombay labels.

From Bujnurd to Kuchan there was a choice of routes, so I selected that one which followed up the course of Atrek, as it had not been travelled over by either Captain Napier or Sir Charles Macgregor, both of whom had pursued the road which keeps further south. Shirwan, which we reached on the second day, is under Kuchan, and is nearly as large as Bujnurd, while the valley of the Atrek, which is here open and undulating, forms one of the most fertile districts of Persia. At Kuchan the walls were in the most dilapidated condition, owing to previous earthquakes, while within a very short time this terrible calamity was again destined to destroy thousands of lives, and then be repeated, to annibilate the remnant that had escaped. At the time of my visit there was a great deal of commercial activity owing to the opening of the road that has brought Meshed within easy reach of the Transcaspian railway at Askabad, while my eves were gladdened by the sight of lines of waggons, which gave quite a civilized look to the place.

For the remaining 90 miles I hired a waggon, its owner agreeing to reach Meshed on the third day; and we started off with the pleasant feeling that this section of the journey was practically an accomplished fact. Unfortunately, at about 5 miles from Kuchan, one of the horses had a violent attack of colic; so we had to halt for the night, as the poor beast was quite unfit to proceed, and it was not until February 28 that I drew up at the consulate-general at Meshed, where I was warmly welcomed by Mr. Ney Elias, whose untimely death this Society is now deploring. In his obituary notice, mention was made of the kindness he showed to all his juniors, and of this I have received innumerable 
proofs during the five years that have elapsed since I was first his guest.

Meshed, as is well known, contains the famous shrine of the holy Reza, the last of the twelve Imams, and is the religious centre of Persia. The mosque is of great magnificence, but has been so fully described by Mr. Curzon, that I would refer to his work in connection with this subject. I was much tempted to linger in the society of my fellow-countrymen; but, as every week's delay meant more heat in the Dasht-i-Lut, I had to hurry through with my preparations, and after a week's stay continued my southward journey. As far as 'I'urbat I was on a well-known road, which had been travelled over by Dr. Bellew in the seventies; but between Turbat and Jumain I found that several villages shown on the map were in ruins or unknown, while the river, termed the Kal Salah, which is shown as flowing east, actually trends to the west, and is lost in the swamps to the north of Bajistan.

At Tun, I was on the northern edge of the great Dasht-i-Lut, which lay between us and Kerman, and which had not been traversed, in this particular portion, since the illustrious Marco Polo crossed it, in the opposite direction, when travelling from Kerman to "Tonocain "vi Cobinan. As the great Venetian was not only a most accurate observer, but also wielded a graphic pen, I feel sure that I cannot do better than give his words, when describing the Dasht-i-Lut, which signifies the "Naked desert"-a most appropriate name. He says, "When you depart from this city of Cobinan, you find yourself in a desert of surpassing aridity. There are neither fruits nor trees to be seen, and what water there is is bitter and bad, so that you have to carry both food and water. The cattle must needs drink the bad water, will they nill they, because of their great thirst." Friar Odoricus, in the succeeding century, who was apparently struck by another phase of the desert, describes it in the following lines. He says, "Now, that sea is a wondrous thing, and right perilous. For it is all of dry sand, without any moisture, and it shifteth, as the sed doth when in storm, now hither, now thither; and as it shifteth, it maketh waves, so that countless people travelling thereon have been overwhelmed and drowned, and buried in those sands."

Our chief preparation consisted in engaging a few donkeys to carry forage for our mules, and, as there were said to be tanks with water ou the way, we expected very little trouble. We soon left the Tun oasis behind, and entered the silent desert, where not even a crow is to be seen. At the fourth mile was a tank of sweet water, where I insisted upon filling up my private water-skin, and at night we halted near the well of Khushab, which means "sweet water." It was much too salt for me in spite of its name, so I was very glad that I had taken the precaution to fill my " mussuck." On the following morning, after drinking tea, only a pint remained; but wo were plomised excellent water 
at the evening's stage of Chahar Gunbaz, and so commenced the march in hope. Throughout the day we approached a snow-clad range, which appears'on no map, and, as we were at the end of March, I estimated its height at 7000 or 8000 feet. The heat and thirst were very trying and, to add to our discomfort, the water at the stage was simply green with salt. I attempted to drink it with lime-juice tablets dissolved in it, but in vain, and so I could only envy the others, who were able to swallow it with apparently no ill results.

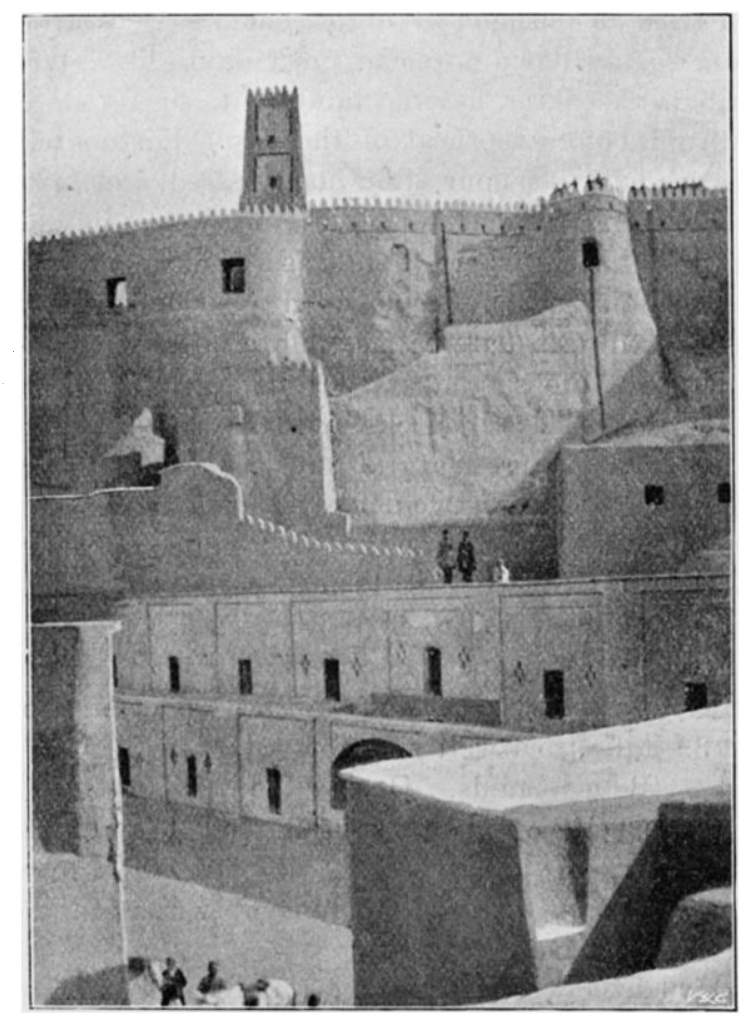

THE FORT A'T BAM.

We were only about 15 miles from Duhuk, which lay under the range referred to; so, after a sleepless night, we pressed on as soon as it was light, and by 10 a.m. we were able to enjoy beautiful water running down from the hills. The villagers were anxious to see the first European that had passed that way, and, considering their isolation, knew a good deal about what was going on in the world. We had to halt a day, as every one experienced such bad effects from the water of the day before, that I was most thankful not to have touched it. 
Duhuk is built in a gap half a mile wide, which separates the Tabas Kuh-the general name for the chain of mountains between Tabas and Duhuk-from the Mur Kuh, which latter range runs southsouth-east towards Naiband.

The onward journey lay through Arababad and Zenagun, where we saw palm trees for the first time. Anotber waterless stretch separated us from Naiband, so, warned by experience, we hired three donkeys to carry water, and marched to Ab-i-garm, where there are extensive salt marshes and groves of tamarisk. As we had still many miles to accomplish, I tried to push on at night, but we were afraid of losing the track, and so lay down to sleep until daylight. Our water was again exhausted, the skins having tainted it, so I rode on, in order to reach Naiband before the heat of the day. Fortunately the track was fairly distinct, but as hour after hour passed, and my pony began to be dead beat, I feared that I had lost my way, especially as there were two or three places where there was a choice of routes. Finally, however, I turned a corner and came upon a vision of fairyland. The hillside was covered with date palms, underneath 'which were glimpses of the bright green crops, and at the summit was an old fort in a state of picturesque ruin. Upon entering the grove, I saw streams in every direction, while huge natural grottoes completed the picture. My first care was to send off two donkeys laden with water, in charge of a man who knew the country, and in the evening the caravan crawled in, the water having reached them some 5 miles out, when they were all feeling too much exhausted to go another yard.

Two or three days were spent in climbing about the Naiband range, while the mules were recovering, and we then traversed another waterless stretch of 39 miles, to a well with forty steps, which was said to be a favourite spot for Beluchi raids. During the next stage to Darband, we passed ruins that I believe to be those of Marco Polo's "Cobinan," as the modern Kuhbenan does not at all fit in with the great traveller's description, and it is just as well to remember that in the East the caravan routes seldom change.*

We now skirted the western edge of the Dasht-i-Lut, and followed the main caravan road until at Ab-Bid we kept away to the east of the main road in order to explore the district of Kuhpayeh, which was then a blank on the map. We approached Kerman from the east, and I little thought that within so short a time it was to be my home. The city lies at the end of a low limestone range, and was once impregnable, to judge by the huge old forts that are still imposing in their decay. Its position on the confines of the great desert, and at the confluence of four important routes, has always rendered it of

* This question is dealt with more fully in a paper which I read before the Society of Arts on May 20. 
importance, but, being on the frontier of Afghanistan, it has suffered terribly at each invasion from that quarter, as well as in the great fight for power that took place at the end of last century. Situated at an altitude of 5500 feet, its climate is extremely pleasant, while its inhabitants are particularly friendly to Europeans. At the present day, it is on account of its carpets that Kerman is justly renowned, although very few of the finer qualities are exported to London. These exquisite fabrics, woven in silk and wool, reproduce designs dating from many

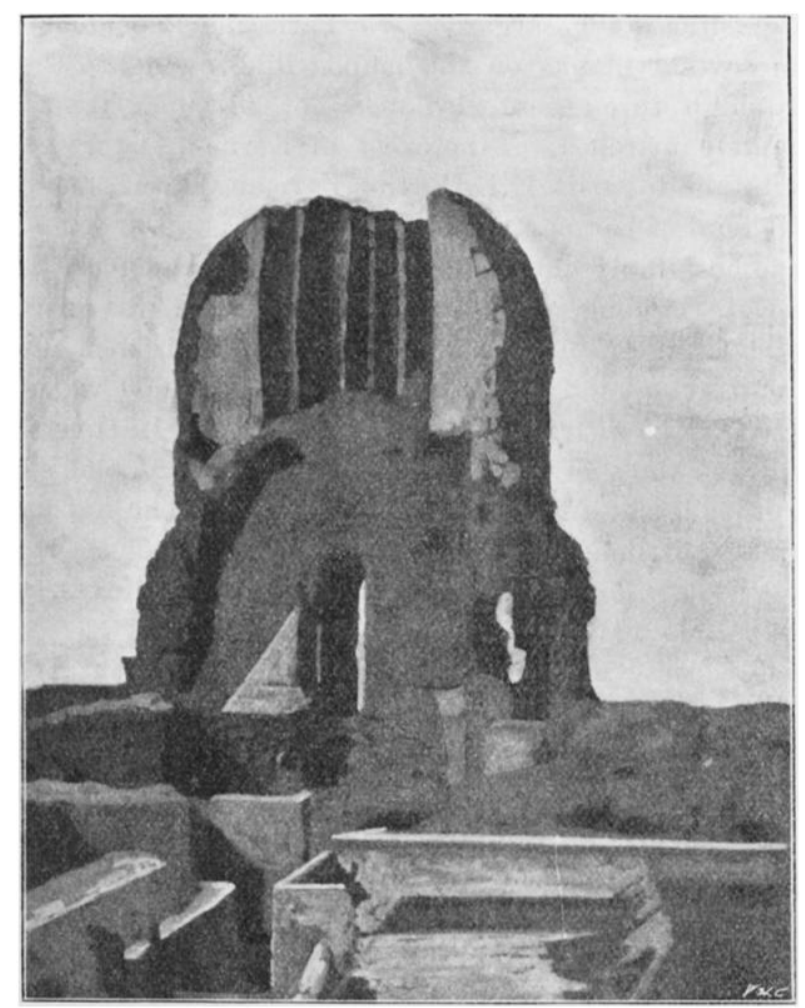

KUBEH-I-SUBS OI "GREEN DOME" AT KERMAN.

centuries back, while the harmonious and lovely colours throw all other carpets into the shade. Among the buildings of interest now extant is the Kubeh-i-Subs, or "Green Dome," which contains the following inscription :- "The work of Ustad Khojeh Shukr Ullah and Ustad Inayet Ullah, son of Ustad Nizam-i-Din, architect of Isfahan." The date is 640 Anno Hejrah, or 1242 Anno Domini. Our interest is considerably augmented by the fact that we know that Marco Polo was at Kerman shortly after this date. In the illustration it will be No. VI.-December, 1897.] 
noticed that there is but half of the building still standing; this is not the result of an earthquake, but is the handiwork of a former governor, who had heard a rumour that treasure existed under the great dome.

During my stay of a week I met several of the merchants of the place, both Mohammedan and Parsi, and I was particularly struck by their polished manners, which are, I afterwards heard, renowned throughout Persia.

About the middle of April, after a few days' rest, I determined to take a straight line to "Pasargardæ" viâ Pariz and Baonat, as thereby I could fill in several blanks on the map, while, owing to the altitude being fairly high throughout, I hoped not to suffer from the heat. When some five marches to the west of Kerman, I received a most cordial invitation to visit H.R.H. the Farman Farma, who was the Governor-General of Kerman and Persian Baluchistan, and, upon accepting it, was so hospitably entertained that I accompanied my new friend to Bahramabad. Among many other experiences, I was introduced to the sport of shooting gazelle off horseback, which consisted in the riders spreading across a plain with intervals of 500 or 600 yards between each, and driving the quarry off its feeding-ground. In time the gazelle break back, when the sportsmen gallop to cut them off, and shoot them with slugs, propelled by a heavy charge of powder. The Farman Farma, who is a great sportsman, on more than one occasion shot a right and a left at full gallop. I have also seen hyenas, lynxes, foxes, and hares bagged in the same way.

When, after being entertained right royally for about a fortnight, I resumed my journey, I had had an agreeable experience of Persian life, enjoyed by very few travellers, coupled with a warm invitation to return during the following winter. Upon entering the unexplored district of Baonat, we. were followed by a band of seven nomads, who were evidently on the look-out to attack us. However, we took all precautions, and maintained a bold front, and, although both my rifle and gun were broken, we carried them in a very conspicuous manner. This band kept parallel to our march for three days, but they fortunately did not otherwise molest us. It is a remarkable coincidence that Captain Stotherd, of the Hyderabad Contingent, was set upon less than a month later, about 30 miles to the south of where I passed, and, although he had only a single orderly with him, he accounted for four of the brigands, killing their chief. It is more than probable that he was attacked by the same gentlemen who took so keen an interest in my movements, and it is satisfactory to feel that Captain Stotherd made so good an impression on them.

Upon arrival at Shiraz, after a visit to the world-renowned ruins at Persepolis, I was most kindly received by Dr. Scully, who told me that I had come at an interesting crisis, as there was war to the death 
between the townspeople and the nomads. The very next morning we were awakened by hearing volleys inside the town, and, climbing up to the roof of the telegraph garden, which is about half a mile from the walls, we saw a regular fight taking place at the gate nearest to us. Fortunately, we were at right angles to the line of fire, and so could look on without much risk, until the nomads, who were greatly outnumbered, finally retreated. During these very stormy times, it was wonderful to see with what utter contempt for danger the English telegraph officials behaved, and it was mainly owing to the confidence felt in their reports at Tehran, that the necessary steps were taken to patch up a peace.

It was now the end of May, so it was necessary to travel by night

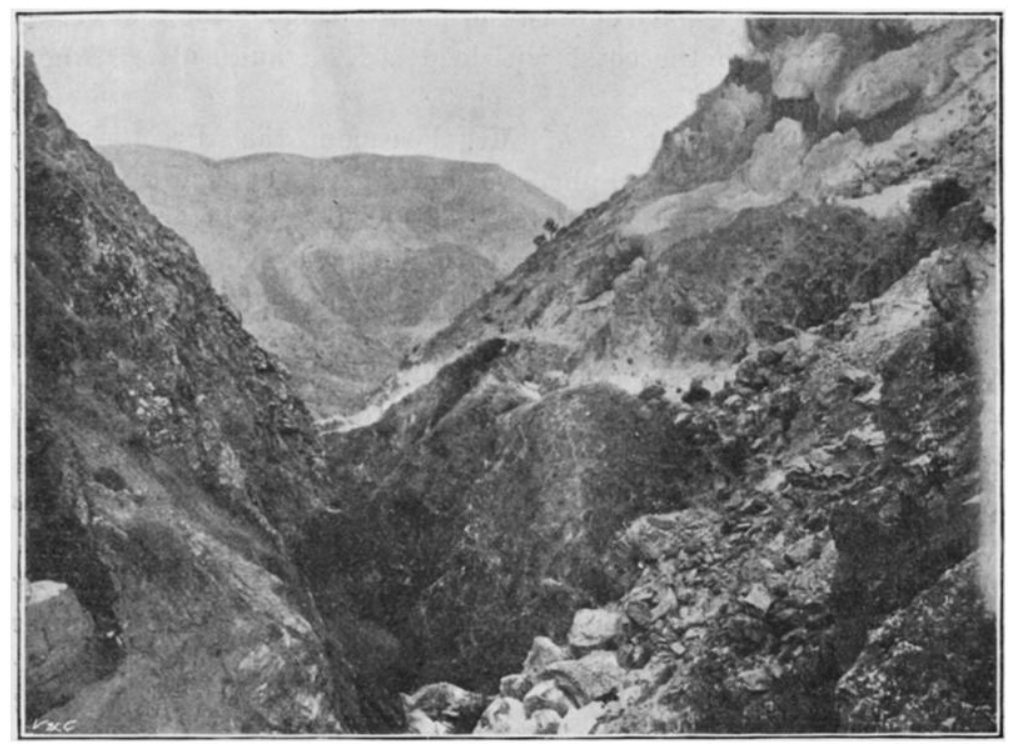

PASS OF THE "OLD WOMAN" BETWEeN SHIRAZ AND BUSHIRE.

down the famous passes of the "Old Woman" and of her "Daughter," which have been so vividly described in Mr. Curzon's monumental work ; and, after turning night into day for nearly a week, I was only too pleased to find myself on board the British India steamer at Bushire, where white bread and a whisky peg appeared to be delicious beyond expression.

Karachi was reached early in June, and the rest of the summer was spent in compiling my work and planning fresh journeys, until, in October, 1893, accompanied by Surgeon-Major Brazier Creagh and Lance Duffadar Sultan Sukhru, of the 3rd Punjab Cavalry, I landed at Chahbar, in Persian Baluchistan. This port was chosen, as since 
Grant's journey, some ninety years ago, no European had travelled to Bampur by Geh.

Before entering Persian Baluchistan, however, a few words as to its character would perhaps not be out of place. The whole of the coastline from Bashikird nearly to Karachi is spoken of as Makran, the district extending inland as far as the first important range of hills, thus including a strip of land from 60 to 70 miles wide. For some 20 to 40 miles from the coast there is a sand desert, with small hamlets, which draw their supply of water from shallow wells. Behind this is another belt of about the same size, consisting of low hills composed of mud or slate. Proceeding further inland, it will be noticed that there are continuous ranges of mountains running from east to west parallel to the sea, and so regular is this formation, that all attempts at opening up communications in these parts must be done either to the east or west, as any road direct to the coast will lead across range after range of rugged hills.

Thanks to the kindness of Mr. Possman, the director-general of the Persian Gulf telegraphs, we found camels awaiting us (at Chahbar), and, owing to the exertions of Mr. Lovell, in charge of the telegraph office, we were able to get twenty-seven of these uncouth beasts of burden loaded up the day after landing. The quarrels as to the partition of loads, and the interest taken by so many people in the camels, revealed to us the fact that several of these animals were divided into legs, each of which had a separate owner. The usual plan, we were informed, was for the driver to have one leg's interest in each camel, which was allowed in lieu of wages and rations.

Our first march brought us to Tez, the famous Arab port in mediæval times, but now no signs of departed greatness exist, except the innumerable tombs of deceased worthies, and we had to drink filthy water out of a shallow hole, and be thankful that there was enough for all our party. Although marching by day was terribly trying for man and beast alike, the Baluchis spent so long in wrangling over the loads, and in tying them on, that it was 10 a.m. before the last of our camels started off for the second march, and, as the heat was terrible, our horses very soon began to give in. We therefore halted for several hours in the shade, near some water-holes, riding on to camp in the evening. We there found only about half of our caravan, the other portion. having halted 2 or 3 miles back, in a rage at being compelled to march some 12 miles, as they said that 7 miles is the limit of a march in Baluchistan. Travellers in this country should be provided with an inexhaustible fund of patience, as the only part that the Baluchi cameldriver plays is to try and prevent any load whatever being put on his camel, while, if at all discontented, he will decump without giving any notice. 
In order to attempt an earlier start, we halted for a day, and then pushed on at sunrise the following morning. However, the march was long, and by the time we reached Pesh Mant our horses had to be led, so utterly prostrate were they. Many of the party also suffered from sun fever, mainly because they got slightly chilled before the sun rose, and so felt the sudden change acutely. After four trying marches, we struck the Geh river, where we decided to make another halt. Just before reaching camp, I saw a couple of wolves, which fact is interesting, as they are not known to exist so near the coast. In the bed of the " kaur," the Baluchi term for river, we found isolated pools of doubtful water at this point; but a march higher up, we came upon a bright flowing stream, bordered by palm groves.

Geh is a large village, built in the fork between two branches of the river, and, with its palm groves, forms a delightful picture. As so many of our party had suffered from fever, we determined to leave the invalids and make a rapid march in light order to Fanoch, returning to Geh by a different route. This we did with great success, finding at Mokht, a village near our route, a remarkable kind of glass bangle, of which I have given specimens to the British Museum.

The pass below Fanoch must be a unique road. For 7 or 8 miles one has to scramble over boulders of the most varied hues, every colour of the rainbow being there, which gives an effect of great beauty. In the case of being overtaken by a "seelab," or spate, in this pass, the loss of the entire caravan would ensue, as the sides are precipitous almost throughout. The morning after our arrival, we set forth to climb the Kuh-i-Fanoch, also termed the Kuh-i-Sufeed, or "White mountain," the summit of which is reached at 4735 feet. After four hot hours spent in climbing, we stood on the top, and were able to look across to the unknown districts lying to the west, while to the north we could clearly descry the shapely Basman peak.

Upon returning to Geh, we retraced our steps down the pass, and then kept further north, striking the Sirha river at Ichan, called "Hochan" by Captain Grant. Both when going to and returning from Fanoch, we crossed the Maluran river, ${ }^{*}$ which is shown as draining

* The following is the list of villages on the Maluran river:-

Matkun, right bank.

Kuchink, ,,

Abgah, ,

Nasperan, ;

Ladgoju, ieft bank.

Aband, right bank.

Margan, ,
Shernani, right bank.

Yark, ,

Murdosmah, ,

Maluran, left bank.

Chah Ali, ,

Wajbis, ,

Korandab, , 
into the Geh river, whereas it is really a tributary of the Kaur-i-Binth.* Along its banks, as well as those of the Sirha river, there are almost continuous lines of date groves. The Sirha pass, which lay between us and Bampur, beggars description, and I am still surprised that we got safely over it, as I should never have believed that laden camels could climb up the cliffs they did without accident. My companion's mare indeed fell, but luckily there was a deep pool below, so no harm was done.

At Bampur we found that Pahra-the Pura of Arrian-was now the seat of government, and so pushed on there, where we were received by the Assad-i-Dowleh, who is a fitting ruler for such a wild race. He was civil enough, thanks to the Farman Farma; but when we informed him of our intention of touring in Sarhad, he tried to discourage us by every means in his power. Having engaged camels with extreme difficulty, we marched due east to Magas, where the kindest inquiries. were made after the late Sir Oliver St. John. We then turned north. into unexplored country, and, at the end of December, reached Khwash, the capital of Sarbad. This word has been written and spelt in so many different ways, that I would mention that it is the Sarhaddi method of pronouncing "khosh," meaning "sweet."

We were now close to the giant range whose highest peak is the great volcano of Taftan, or the "boiling," locally known as Chehel Tan, or the "Mountain of the Forty Beings," and as we were afraid that snow might hinder our ascent, we marched up its valley, where

The following is the list of villages on the river Sirha from Ichan downwards :-

Kondel Mant, right bank.

Aband, left bank (opposite Mullah).

Deh Mullah, right bank.

Khushk, left bank.

Gurani, right bank.

Mirabad, left bank.

Shah Karpad, left bank.
Geladun, left bank.

Deh Washkosh, right bank.

Bandan, Pothan (opposite Bandan), left bank. Mokht, right bank. Afzilabad, left bank. Hudian, ,

Thence 4 miles to Naokinja, where I halted between Chahbar and Geh.

I crossed both of these streams at two places, some miles apart, so that I have reason to believe in the accuracy of the above list.

* There are five streams which make up the Kaur-i-Binth, as the Fanoch river is called below the pass. Beginning from the west-

1. The main stream, up which runs the road to Ramishk. Mirabad is the only village of importance that we could see.

2. Kaur-i-Kantekon. This stream flows almost due north to south.

3. Kam Kaur, with village of Kam just above Fanoch, and Haimini on an easterly branch.

4. Kaur-i-Magen, with two hamlets, Magen and Band-i-Bengi, on its banks.

5. Kaur Espate. This stream flows in just below Fanoch, the hamlet of Espate: being some few miles up it. 
we camped at an altitude of 6550 feet, near a large cave, which protected our horses from the intense cold. My companion was unfortunately ill, so, as the weather looked very threatening, I decided not to wait, but to make the attempt on the following morning.

For 7 miles the track led up the valley, which then terminated in an extraordinary fissure, termed the Band-i-Gelu. Creeping up this, we found ourselves in a valley, which smelt strongly of sulphur, but the going was easy enough until we began to climb the actual peak. First of all, we had to scramble over boulders, but these at 11,000 feet were replaced by soft lava ash, so that it was 2 p.m., after eight hours' incessant climbing, when we reached the summit at 12,850

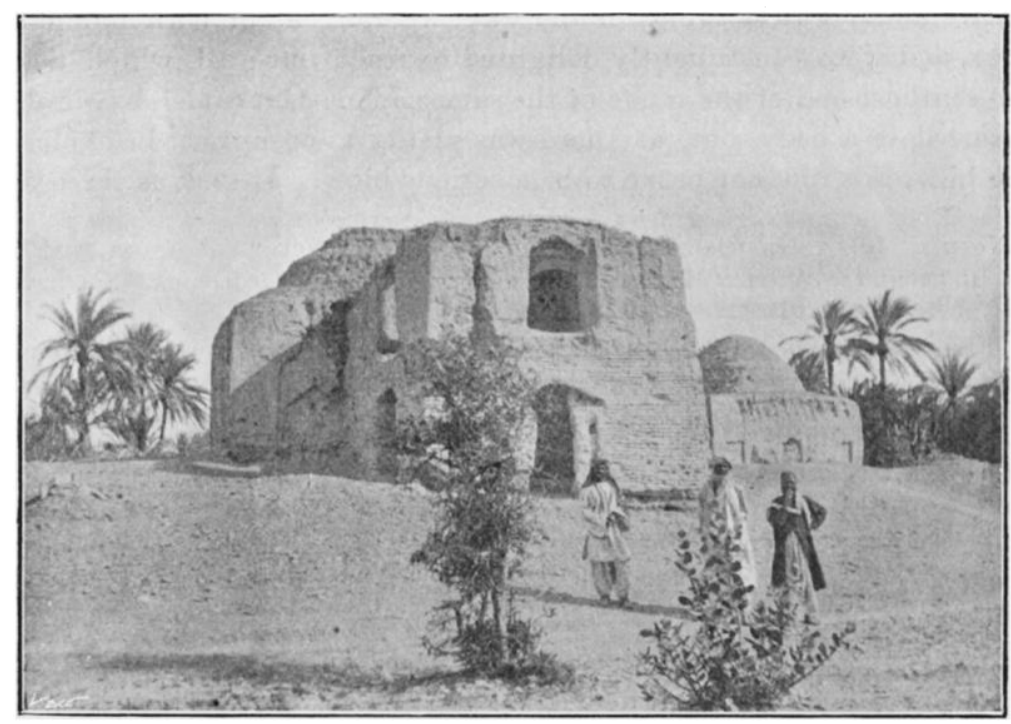

TOMBS OF THE KAIANIAN MALIKS AT JALK.

feet. We here found a plateau about 400 yards square, the northern portion of which is termed the Kuh-i-Ziarat, or " Sacrifice hill," while separated by a slight depression lay the Mader Kuh, or "Mother hill," which is still the actual object of worship for most Sarhaddis, although nominally they are Mohammedans. The volcano, which was belching out blinding clouds of sulphurous smoke, consists of two apertures, each some 3 yards in circumference, which apparently united a few feet below the surface, as there was only a yard or so of ground between them. With considerable difficulty, we extricated specimens of the sulphur and sal ammoniac, and then turned our attention to plane-tabling. At the elevation we were at, we could see Sistan and the lake of Zirreh, mentioned in Matthew Arnold's great poem, while to the north-west 
the boundless Dasht-i-Lut stretched for hundreds of miles. The descent was easy, in comparison, and by 9 p.m. we were safely back again in camp.*

The whole of this valley is full of ruined villages, and opposite them are oval-shaped caves hewn out of the rock. These were some 8 feet in length, 6 feet in width, and 5 feet in height. No marks of smoke were visible, and, as they were very difficult of access, I would hazard the theory that they were humble imitations of the rock tombs at Pasargardæ.

After stopping long enough to allow my companion to scale the great volcano, on New Year's Day, 1894, we started forth to find the village of Basman, the whereabouts of which was uncertain to a degree. As we could buy nothing on the way, we ran out of both forage and flour, and were consequently delighted to reach our goal, which lies at the southern end of the range of the same name. Our camel-drivers here deserted in a body, but, as there was plenty to occupy $u_{s}$ in exploring the hills, this did not prove to be a serious blow. It took us three days

* Note by Lieut.-Generai. McMahon in a Paper on the "Volcanoes near the Beluchistan-Afghay Frontier," read before the Geological Society on MaRch 24, 1897.

"Since this paper was read the authors have been in personal communication with Captain P. Molesworth Sykes, now in England on leave, who ascended the mountain on Christmas Eve, 1893. After gradually ascending ravines in the hills around the mountain, the exploring party arrived at the foot of the actual cone at an elevation of 10,000 feet. Thence up to 11,000 feet the ground traversed cunsisted of boulders ; but from 11,000 feet upwards it was covered with fine volcanic ash, into which the foot sank deeply at every step. From this point up to the top the smell of sulphur was unpleasantly strong. The summit consists of a plateau covering an area of about 400 square yards. On its northern and southern sides the ground is slightly elevated above a central depression. The northern elevation forms the sacrifice hill, where goats are sacrificed by pilgrims; whilst the southern portion is called Mader Kuh ('Mother hill'). On the latter were, at the time of Captain Sykes's visit, two apertures some yards apart, each apparently 3 or 4 yards wide, which appeared to be connected with each other. From both of these, dense white sulphurous smoke and some flames were issuing. So strongly sulphurous and suffocating was the smoke, that these apertures could only be approached from the windward side; and, owing to the heat and smoke issuing from them, they were approache $d$ with difficulty even from that side. Sulphur and sal ammoniac were extracted from the edge of one of the apertures.

"Captain Sykes has paid several visits to the burning petroleum springs at Báku, on the western shore of the Caspian sea, and he is satisfied that the heat, smoke, and flames on the summit of the Koh-i-Taftán were not due to petroleum. There was no smell of petroleum, and the smoke was not dark and carbonaceous.

"Captain Sykes brought home a specimen of the rock found in situ on the Koh-iTaftán, and this proved, on examination, to be a vesicular, andesitic lava. As the summit of the Koh-i-Taftán is still deeply covered with fine ash, this voleano must have been active during a comparatively recent geological period; but, as no fresh lavastreams were observed by Captain Sykes on his way up the mountain, it is not probable that the volcano has been active during the lifetime of the present generation.

"The authors infer, from Captain Sykes's observations, that the volcano is now in the solfatara stage of its existence. The flames seen by Captain Sykes are probably due to the emission of hydrogen sulphide $\left(\mathrm{H}_{2} \mathrm{~S}\right)$, a very common product of solfatara action." 
to scale the great peak, from our camp at Basman village, but at last we arrived at the summit, and set up the plane-table at an altitude of 11,210 feet above the sea. We were on what is generally supposed to be an extinct volcano, and it is interesting to note that even here there is a legend of a saint called Kedr, who still lives in the mountain, just as in Greek mythology a giant is imprisoned beneath Etna. The mountain is locally termed Kuh-i-Zendeh, or the "Mountain of the Living Man."

Upon returning to Basman, we enjoyed excellent moufflon-shooting, until the Farman Farma sent some of his transport for our use, and we rejoined him at Bampur. In his company, we travelled along the

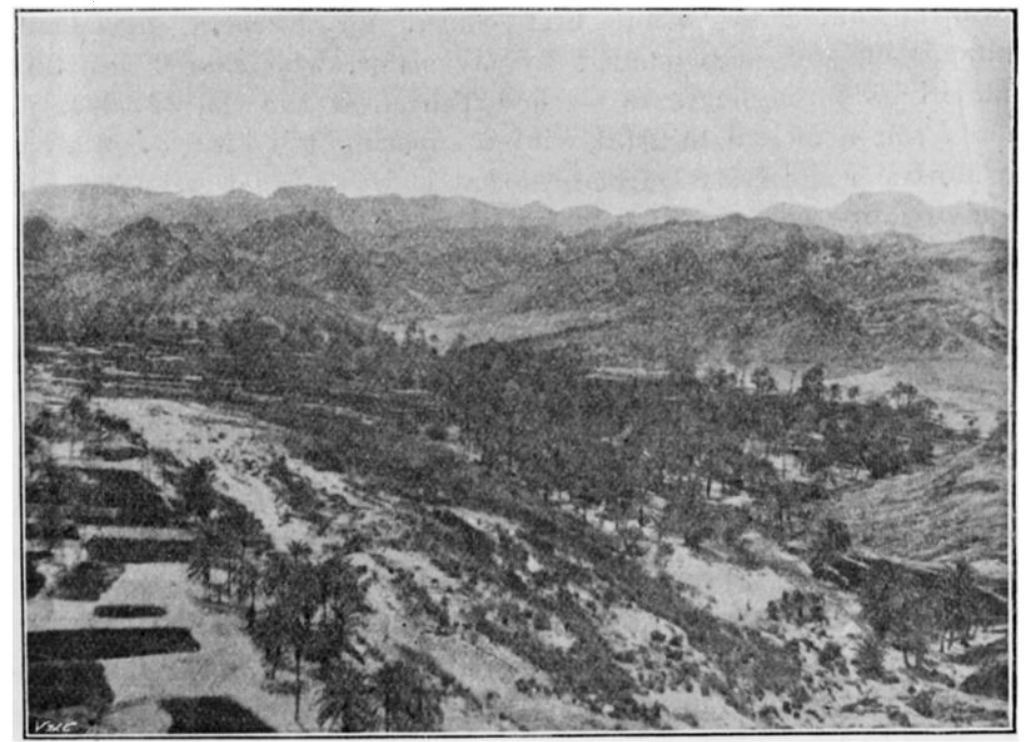

THE LAJJI VALLEY ON THE BELUCH-KALAT FRONTIER.

unexplored tract of country where the Bampur river and the Halil Rud mingle their waters in the Jaz Morian. Additional interest was felt by us, knowing it to have been the road that Alexander the Great used in his march from India.

Upon arrival in Rudbar, we turned northwards and left the Farman Farma, in order to explore the site of Marco Polo's "Camadi," where the china exhibited, together with the seals and other curios, were found. We came upon a huge area littered with yellow bricks 8 inches square, while not even a broken wall is left to mark the site of what was formerly a great city, under the name of the Shehr-i-Jiruft.

It was now late in March, so we were only too glad to traverse the Jabal Bariz range and gain the elevated plateau of Iran, and, just a year 
after my first journey, I again entered Kerman. Here our party broke up, Surgeon-Major Brazier Creagh returning to India by Bunder Abbas, while I continued my journey towards Tehran. At Yezd I was most hospitably entertained by the manager of the Imperial Bank of Persia, and at Tehran, Mr. Coningham Greene, Her Majesty's chargé d'affaires, not only made me free of the Legation, but also presented me to H.I.M. the late Shah, who was interested at hearing about so remote a corner of his empire. I travelled to England in rather over a fortnight by the newly opened line from Petrorsk, on the Caspian sea, taking the faithful Sultan Sukhru with me as a reward for his excellent work, and reaching London late in June.

After four months at home, spent in compiling my second journey, I was appointed to be the first consul for Kerman and Persian Baluchistan, and, accompanied by my sister, who shared my future wanderings throughout, we reached Tehran at the end of 1894 . We there spent a most delightful winter, enjoying the kind hospitality of Sir Mortimer and Lady Durand, so that it was a great wrench to leave all civilization behind and start forth on the long journey of 600 miles, which lay between us and my district. As far as Kashan, we followed my route of 1894 , but for the onward march to Yezd I kept a good deal to the east, passing through Natunz and Kuhpa. Thereby I was able to fill in a large blank that has existed on the map quite close to Ispahan, while, as so often happens in Persia, I found the district to be quite as populous as the one bordering the main road.

Kerman was reached at the end of March, and for some months we were busy enough, what with consular work and settling down. When, however, it grew hot in June, I determined to explore Sardu, so as to trace out Marco Polo's route, and we had a most delightful trip while occupied with this task, during which we scaled the highest peak of the Lalazar range, 13,700 feet above sea-level-no mean feat for a lady to accomplish. There was also the best of moufflon-shooting, and we picked up several carpets woven by the nornads, while the climate at an altitude of over 8000 feet was perfection. However, we were forced to return home by quick marches to meet H.R.H. the Farman Farma, who was once again appointed governor of the province, and the autumn was spent at Kerman, as we found interesting occupation in trying to unravel the ancient history of that city. I cannot say we were unsuccessful, as our offers of a reward for old stones and curios produced a number of reflet tiles, and I am proud to state that we captured a wasp unknown to science, when collecting insects for a friend.

In January, 1896, telegraphic orders came for me to join Colonel, now Sir Hungerford, Holdich on the Perso-Beluch frontier, which instructions I should have been quite unable to obey, without considerable delay, had not my kind friend, the Farman Farma, lent me his own transport. 
Thanks to this, we started off on the third day, leaving our household gods to look after themselves, and within a week we had reached Bam, until recently the frontier fortress of Persia. Everywhere I was shown the greatest courtesy, so that forage and supplies, which usually are impossible to collect, were ready at each stage, and from Regan, with only a day's halt, we were able to load up fifteen extra camels with all supplies, before crossing that portion of the Dasht-i-Lut which lay between us and Pahra. There my old acquaintance, the Assad-iDowleh, treated us well, and it only took two days to engage thirty spare camels and to load up supplies for twenty days, as the villages:

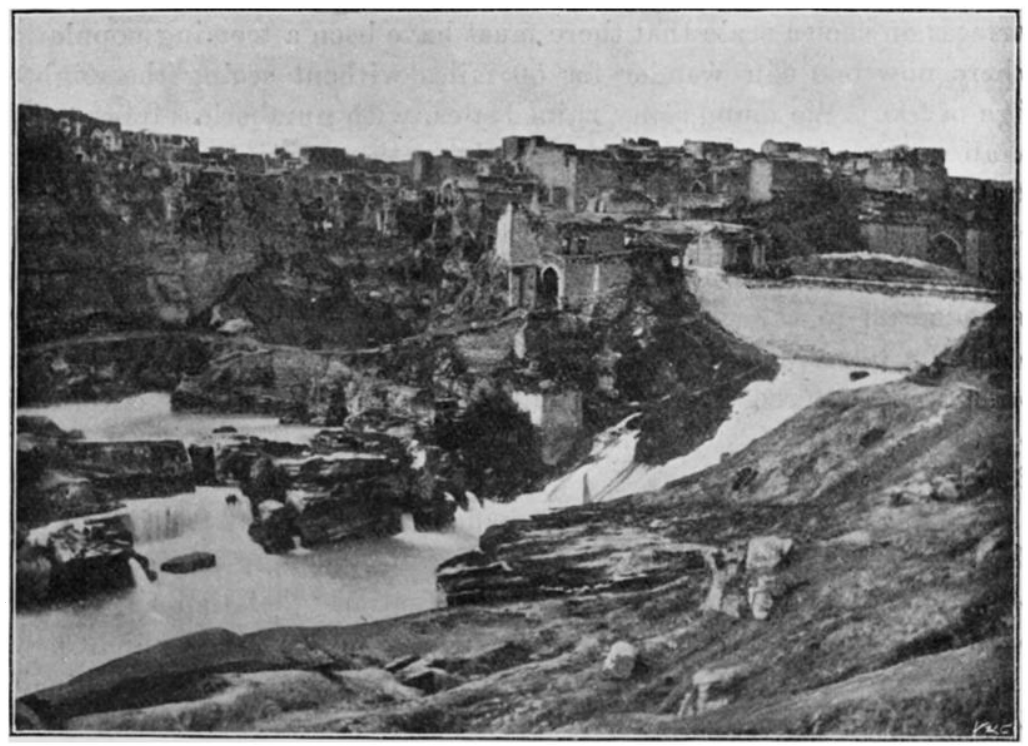

THE WATER-MILLS OF SHUSTER.

to the east were too small to be counted upon to any great extent. As far as Magas, we followed the route that we had taken in 1893, after which we continued nearly due east, reaching the British camp at Kohuk on February 24, having accomplished the march of 600 miles, mainly across desert, in forty days.

Sir Hungerford Holdich * has already read an interesting paper about the geographical side of the frontier commission, during which we marched with our headquarters as far as Jalk, while excursions were made to the various points of interest along the frontier. Both at Jalk and Kohuk we found numerous tombs which were built by the Kaianian maliks, and which appear among the illustrations. On one

* Geographical Journal, vol. ix. p. 416. 
of them I found a brick bearing the date of 1027 Anno Hejra, or 1617 of our era. This confederacy of chieftains appears to have ruled in Sistan and Baluchistan during the prosperity of the Sefavi dynasty, and, as far as we know, they were crushed by Nadir Shah about 150 years ago, although Pottinger mentions that they still owned villages early in this century.

We accompanied the British Commission on its long march to Quetta, so that my sister may claim to be the first lady who has ridden from the Caspian sea to India, a distance of nearly 2000 miles. While travelling up the valley of the Rakshan, through what is now a desert, we saw that for miles the country had been cultivated in terraces on such a scale that there must have been a teeming population, where now one can wander for 50 miles without seeing the slightest sign of life. We found many ruined sites, with numberless fragments of Arab pottery, beads, and bracelets, and felt that it was only deforestation that could have changed the country from a smiling plain of plenty to "a barren and dry land, where no water is." Daily, the thermometer registered over $90^{\circ}$ in our tents, so it was with light hearts that we ascended on to the uplands of Baluchistan, until, at Kalat, we again reached a telegraph wire-that pioneer of civilization-and at the end of April we entered Quetta, where we were all most kindly entertained by the late Sir James Browne, whose name will live long on the Beluch country side.

We were on the way to Simla, when the sad news of His Majesty the Shah's death reached us, and it was quite touching to see how much our Persian servants felt the calamity that had befallen their native country. Nearly a month was spent in Simla, during which I was enabled to compile my work up to date, and at the beginning of June we were once again at Karachi, bound for the Karun valley. We were caught by the beginning of the "monsoon," and, as we were on board the worst roller that the British India Company possesses, we were very glad to reach the shelter of the Persian Gulf. For the first time, I visited Bahrein, when we rode on donkeys to the famous wells, and also saw the extraordinary phenomenon of a spring of fresh water bubbling up in the sea, which is very shallow indeed all round the islands. The pearl fisheries were in full swing, and it was a most picturesque sight to see the fleet of little vessels all busily engaged in fishing for oysters. The weather was too hot and our stay too short for a visit to the site of Sir E. Durand's and the late Mr. Theodore Bent's excavations; but there are few places so accessible that would, in my humble opinion, yield a richer harvest than this ancient home of the Phœnicians, where Erythras, the "Red King," lies buried.

Off Bushire we again experienced rough weather, but when once we entered the lovely Shat-el-Arab, the moist heat was overpowering, and as, at Mohamerah, we found that the fortnightly boat was not due to 
start up the Karun for another week, we continued our journey to Busreh, where Captain Whyte, Her Majesty's consul, received us most hospitably.

Before entering the valley of the Karun, I would mention that that river was opened to the commerce of the world in 1888 , and that ever since Messrs. Lynch Brothers have maintained a fortnightly service, in spite of much hostile intrigue on the part of some of the inhabitants of this district, who did their best to thwart the Shah's policy. However, the extraordinary tact of Messrs. Lynch's agents has overcome much obstruction, and every one is now alive to the advantages that they have conferred upon the district, so that we may soon hope to see this system of mutual benefit placed on a thoroughly sound and solid basis.

It is but 117 miles from Mohamerah to Ahwaz, but this occupied the best part of two days to accomplish, as we anchored at night. At Ahwaz, where a few years ago there were but wretched huts, warehouses and caravanserais of imposing appearance now line the bank, while great activity is everywhere visible. After spending a few days with Messrs. Lynch's agent, Mr. Parry, in his company I proceeded up to Shuster on the s.s. Shushan, the larger boat, the s.s. Mal Amir, not being able to surmount the natural barrage that crosses the river in five separate reefs. This is the crux of the Karun question, as, if the ancient dam were repaired, there would be water enough to fertilize millions of acres which now lie idle and useless. At Shuster, one of the dirtiest, hottest, and most fanatical towns in the world, we lived in cellars for the greater part of the day, as at 8 a.m. the thermometer regularly registered $108^{\circ} \mathrm{Fahr}$., while at noon $129^{\circ}$ was the average reading. As may be supposed, we were only too glad to return to the comparatively cool climate of Ahwaz, where I had left my sister, and here July was spent. In August, I was so weak from fever and pleurisy that I had to seek medical advice at Busreh, and again enjoyed every comfort at the consulate, for which I shall ever be grateful. The moist heat was so trying that the doctor ordered a sea voyage, so that early in September we returned to Tehran by the roundabout way of Bombay, Aden, Brindisi, and Constantinople.

I was very anxious to have the Ahwaz-Ispahan road properly mapped as far as its junction with the Shuster route, as, until quite recently, Ahwaz barely existed, and so there was no road running to it shown on the map. Here the great value of my faithful plane-tabler came in, as I was able to send him in charge of my caravan through the Bakhtiari country and feel quite confident that when we met again at Tehran, he would have an excellent route report to give in, in which hope I was not disappointed.

The winter was again spent under the same hospitable roof at Tehran, where I saw H.I.M. Muzzufur-i-din Shah more than once, who evinced. 
much interest in the photographs that I had taken on the Baluch frontier. Moreover, I had the opportunity of making the acquaintance of the leading Persian statesmen, one of whom, His Excellency the Nasir-ul-Mulk, is here to-night, having paid us the compliment of returning to England the moment his official duties on the continent were finished.

In conclusion, I would mention that, after travelling for many thousand miles in Persia, I still wish to travel there again, and, although perhaps the free open-air life and the glorious/climate have something to do with this, I cannot but feel that it is also owing to the Persians themselves being so hospitable and friendly a race.

Before the reading of the paper, the President said: We have to welcome here this evening an officer who has seen a good deal of a very interesting part of Persia, and from whom we have received several letters of great interest, though I believe we have not before had the pleasure of listening to him in this room. I will now call upon Captain Sykes to read his paper.

After the reading of the paper, the following discussion took place :-

The President : I would now ask his Excellency, Nasir-ul-Mulk, to open the discussion by some observations.

His Excellency, the NASIR-UL-MULK : I am very pleased to have had the opportunity of being present at this meeting, and of listening to the very interesting lecture of Captain Sykes. As you have seen, Captain Sykes has shown himself a very active explorer, and has availed himself of the opportunities afforded him to give you new information about the outlying parts of Persia. I am afraid that all he said was about the outlying parts and the deserts, and that may give you the idea that all parts of Persia are the same. As you know, Central Persia is desert, but the borders are very beautiful and fertile places, and I am sure that Captain Sykes on another occasion will give you information about these parts also. I have to thank him for the kind allusion he has made to myself, and again to express the pleasure I have had in being present at this meeting.

Major-General Sir Frederic Goldsmid : I am afraid that any remarks which I can make on the very interesting paper we have just heard would involve too distant a retrospect to warrant attentive consideration on your part. My knowledge of Persia goes back to so ancient a date, that anything I may now say on that country must be of comparatively little interest. About thirty-four or thirtyfive years ago I had the honour of addressing this Society at a meeting presided over by Sir Roderick Murchison. I had then recently returned from the coast of Mekran, which I had been sent to explore under orders from Bombay. Although we, in Sind, were neighbours to Mekran, we knew very little of that province in those days. I was ordered to go along the const as far as I could, and see whether the country was fitted for the setting up of our telegraph line, whether the people were fitted for protecting that line, and whether I could make any permanent arrangements for its protection. Accompanied by an escort of Sind horse, I reached Gwádar in about seven weeks, exploring and taking notes the whole way, and making my report to the Bombay government. From Gwádar I should have continued the exploration, but was directed to return, lest our little acquaintance with Western Mekran should lead us into political complications. Consequently, I put my camels and horses into boats, and returned to Karáchi. A few years later, I reached this very place, Gwádar, from the neighbouring port of Charbar, 


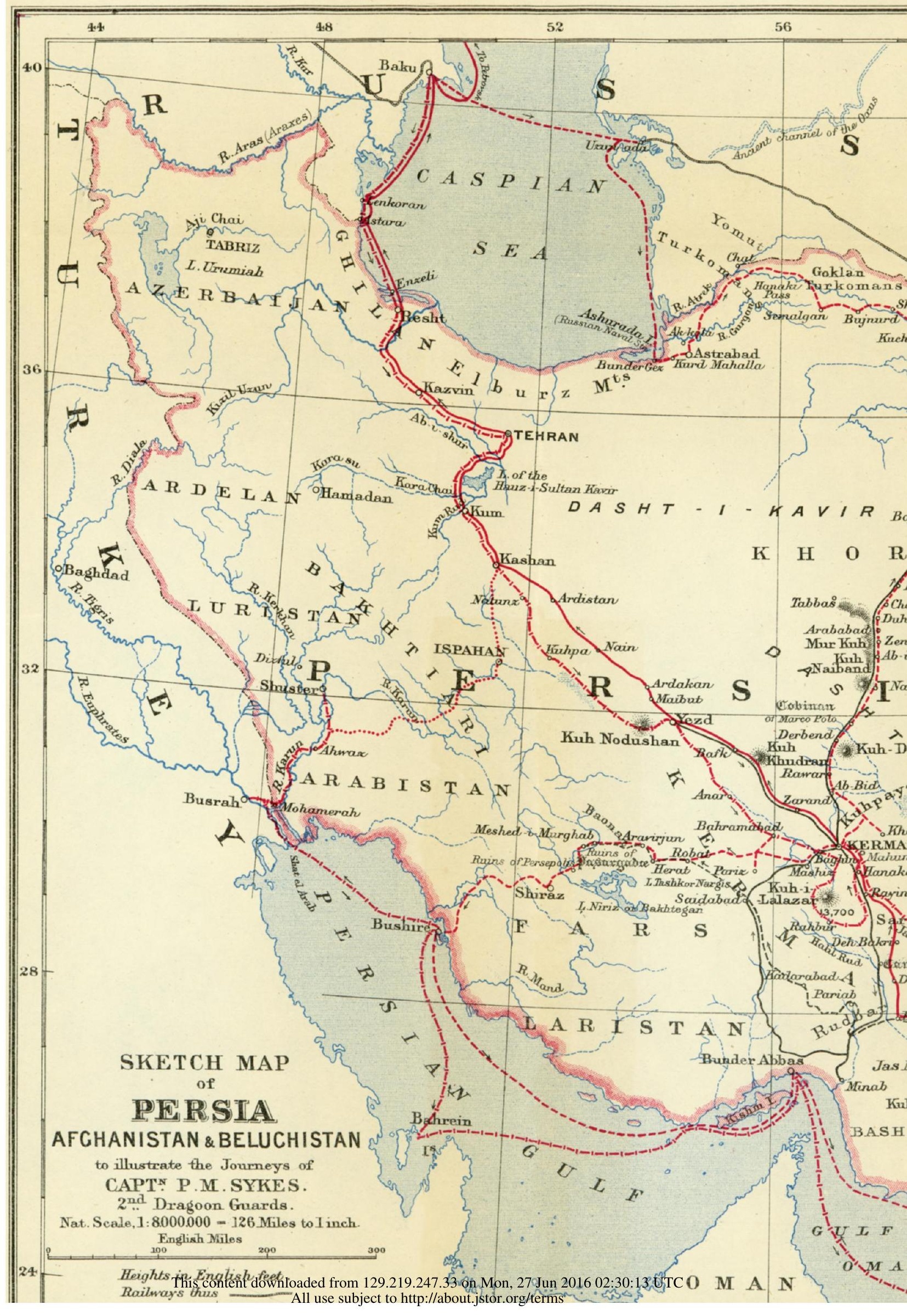




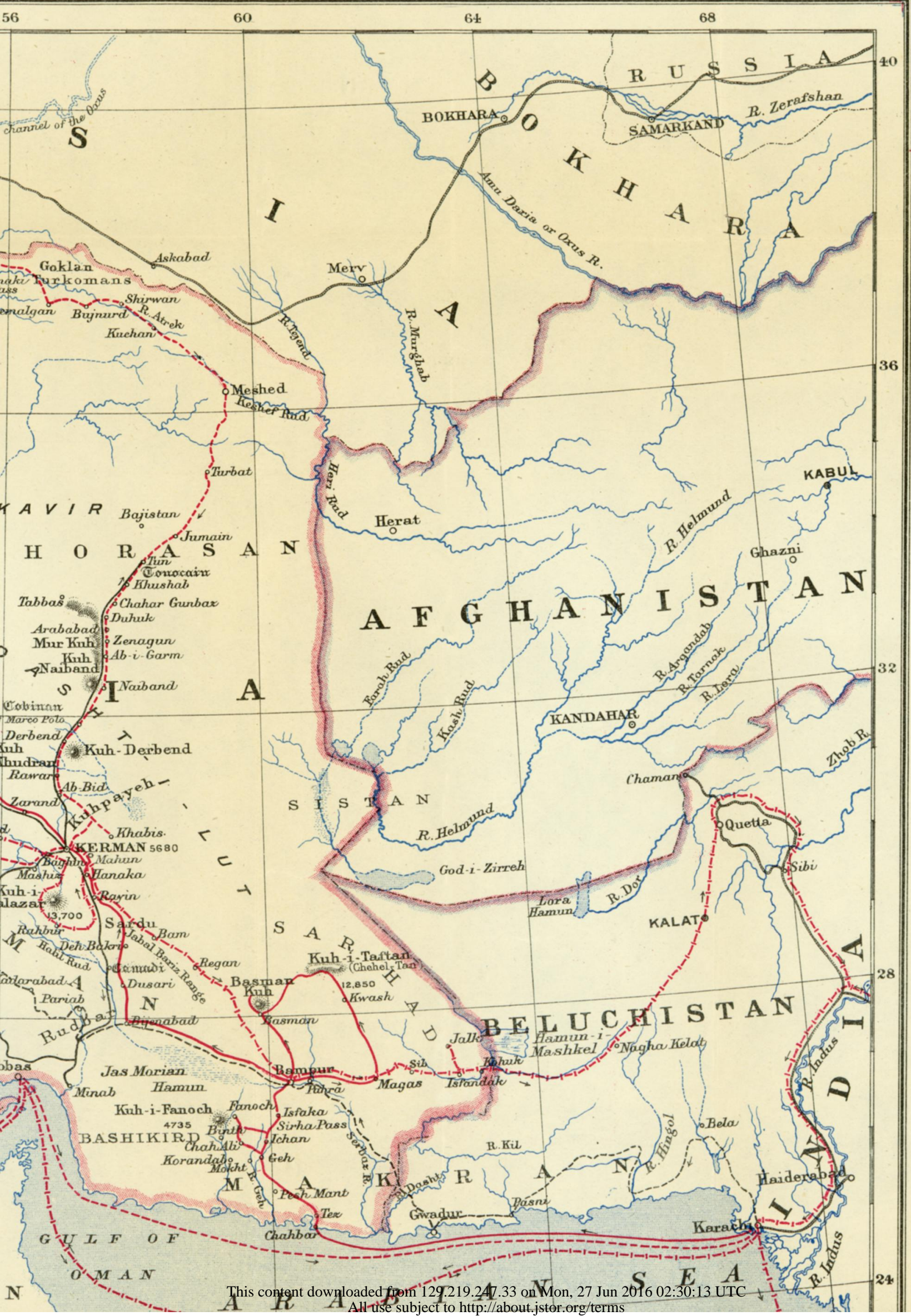


